\title{
2. DETAILED STRUCTURE AND MORPHOLOGY OF THE TAG ACTIVE HYDROTHERMAL MOUND AND ITS GEOTECTONIC ENVIRONMENT ${ }^{1}$
}

\author{
M.C. Kleinrock, ${ }^{2}$ S.E. Humphris, ${ }^{3}$ and the Deep-TAG Team \\ (P. Shaw, ${ }^{3}$ A. Bowen, ${ }^{3}$ T. Crook,${ }^{3}$ C. Davis, ${ }^{2}$ R. Elder,${ }^{3}$ D. Gleason, ${ }^{3}$ J. Goff,${ }^{4}$ L. Goldstein,,${ }^{5}$ W. Handley, ${ }^{3}$ \\ J. Howland, ${ }^{3}$ S. Hussenoeder, ${ }^{3}$ K. Koga, ${ }^{3}$ S. Lerner, ${ }^{3}$ K. Nakamura,${ }^{6}$ M. Rashid, ${ }^{2}$ L. Reiser Wetzel, ${ }^{7}$ W. Sellers, ${ }^{3}$ \\ M. Sulanowska, ${ }^{3}$ C. Van Dover,${ }^{8}$ and L. Whitcomb ${ }^{3}$ )
}

\begin{abstract}
Preliminary analysis of near-bottom, high-resolution DSL-120 sidescan and bathymetric data from the median valley in the TAG (Trans-Atlantic Geotraverse) segment near $26^{\circ} \mathrm{N}$ on the Mid-Atlantic Ridge, and Argo-II photography from the associated actively venting hydrothermal mound, allows us to evaluate the structural, volcanic, and hydrothermal processes occurring in this area, and to provide baseline constraints on the pre-drilling status of the morphology of the mound and the distribution of venting. These data were collected just 2 months before ODP drilling of the active TAG mound, one of the largest volcanichosted, mid-ocean ridge hydrothermal deposits yet discovered. Sharp discontinuities and strong asymmetry in the morphology and age distribution about the spreading axis suggest a recent episode of preferential accretion of crust to the east. Such episodes have likely contributed to the long-term spreading asymmetry $(13 \mathrm{~mm} / \mathrm{yr}$ to the east, $11 \mathrm{~mm} / \mathrm{yr}$ to the west) of the TAG segment. The active mound lies within the intersection of a zone of actively developing ridge-parallel (north-northeast) fissures and a series of pre-existing obliquely oriented (east-northeast) faults. The east-northeast faults are not continuous with faults previously described from the upper rift valley walls. This intersecting fault pattern may be important in localizing hydrothermal activity. Contemporaneous tectonic deformation and hydrothermal deposition continue to modify the three-dimensional structure and hydrogeology of the active TAG mound.
\end{abstract}

\section{INTRODUCTION}

The TAG hydrothermal field lies at the base of the eastern median valley wall on the Mid-Atlantic Ridge (MAR) at $26^{\circ} 08^{\prime}$ N. High-temperature activity within this field is confined to the TAG mound, which has been intermittently active over at least the past $20,000 \mathrm{yr}$, and is currently in an active phase that began $50 \mathrm{yr}$ ago (Lalou et al., $1990,1993)$. This activity has resulted in the formation of one of the largest volcanic-hosted hydrothermal deposits yet discovered along the global mid-ocean ridge system. Although the TAG active mound has been the subject of a number of detailed submersible studies that have included geological observations, magnetics studies, and fluid and substrate sampling (e.g., Chapter 1 [this volume] and Rona et al., 1986, 1993; Campbell et al., 1988; Thompson et al., 1988; Tivey et al., 1993, 1995), the volcanic and tectonic setting of this feature has to be defined before the controls on the localization and episodicity of hydrothermal activity can be constrained.

In June-July 1994, high-resolution sidescan sonar imagery, with co-registered bathymetry, and detailed photographic (electronic still, video, and $35 \mathrm{~mm}$ ) imagery, were collected from Knorr in surveys of the TAG hydrothermal area and its environs (Fig. 1). The purpose of this work was to improve our understanding of the interrelationships

Humphris, S.E., Herzig, P.M., Miller, D.J., et al. 1996, Proc, ODP, Init. Repts., 158: College Station, TX (Ocean Drilling Program)

'Department of Geology, Vanderbilt University, Nashville, TN 37235, U.S.A.

'Woods Hole Oceanographic Institution, Woods Hole, MA 02543, U.S.A.

${ }^{4}$ University of Texas Institute for Geophysics, Austin, TX 78759. U.S.A.

'Department of Mathematics, University of Southern California, Los Angeles, CA 90089, U.S.A.

${ }^{6}$ Geological Survey of Japan, Ibaraki 305, Japan

'Department of Earth and Planetary Sciences, Washington University, St. Louis, MO 63130, U.S.A.

Duke University Marine Laboratory, Beaufort, NC 28516, U.S.A between volcanic, tectonic, and hydrothermal activity along the portion of the MAR segment in which the TAG hydrothermal field is located, and to document on a fine-scale the detailed structure of the active TAG mound before Ocean Drilling Program (ODP) drilling in September-November 1994. In addition, a high-resolution bathymetric map of the TAG active mound was produced, which has been extensively used to facilitate selection of drilling locations and for precise emplacement of monitoring instruments by Japanese (in August 1994) and Russian (in September 1994) submersibles before drilling. All of these cruises were part of an intensive, coordinated investigation that was designed to document the pre-drilling nature of the hydrothermal system, to continue time-series measurements of its physical and chemical characteristics, and to monitor changes related to drilling

This paper presents the preliminary results of the sidescan sonar and bathymetry surveys conducted from the Knorr; it also discusses the regional geology of the median valley in the area of the TAG hydrothermal field, as well as some of the possible structural controls on the location of the TAG active mound. In addition, the detailed bathymetry and selected photographic imagery of the active mound are presented to delineate its morphology and the distribution of different styles of hydrothermal venting.

\section{INSTRUMENTATION AND FIELD STRATEGY}

A nested survey strategy was adopted that comprised two stages (Fig. 1). The first stage consisted of surveying an area of about $10 \times$ $20 \mathrm{~km}$ with the DSL-120 sidescan sonar system. This survey included coverage of the entire width of the median valley floor including the TAG hydrothermal field. The DSL-120 is a $120-\mathrm{kHz}$ phase-difference, split-beam sidescan sonar, operated by the Deep Submergence Lab of Woods Hole Oceanographic Institution, that generates acoustic imagery and bathymetry over typical swaths of about 1000 and 
Figure 1. SeaBeam bathymetry of the TAG segment (Purdy et al., 1990) showing the areas of the DSL-120 (large black box) and Argo-II surveys (small black box). ( $500 \mathrm{~m}$ gray shades; $100 \mathrm{~m}$ contours). Inset shows location of the TAG segment on the Mid-Atlantic Ridge.

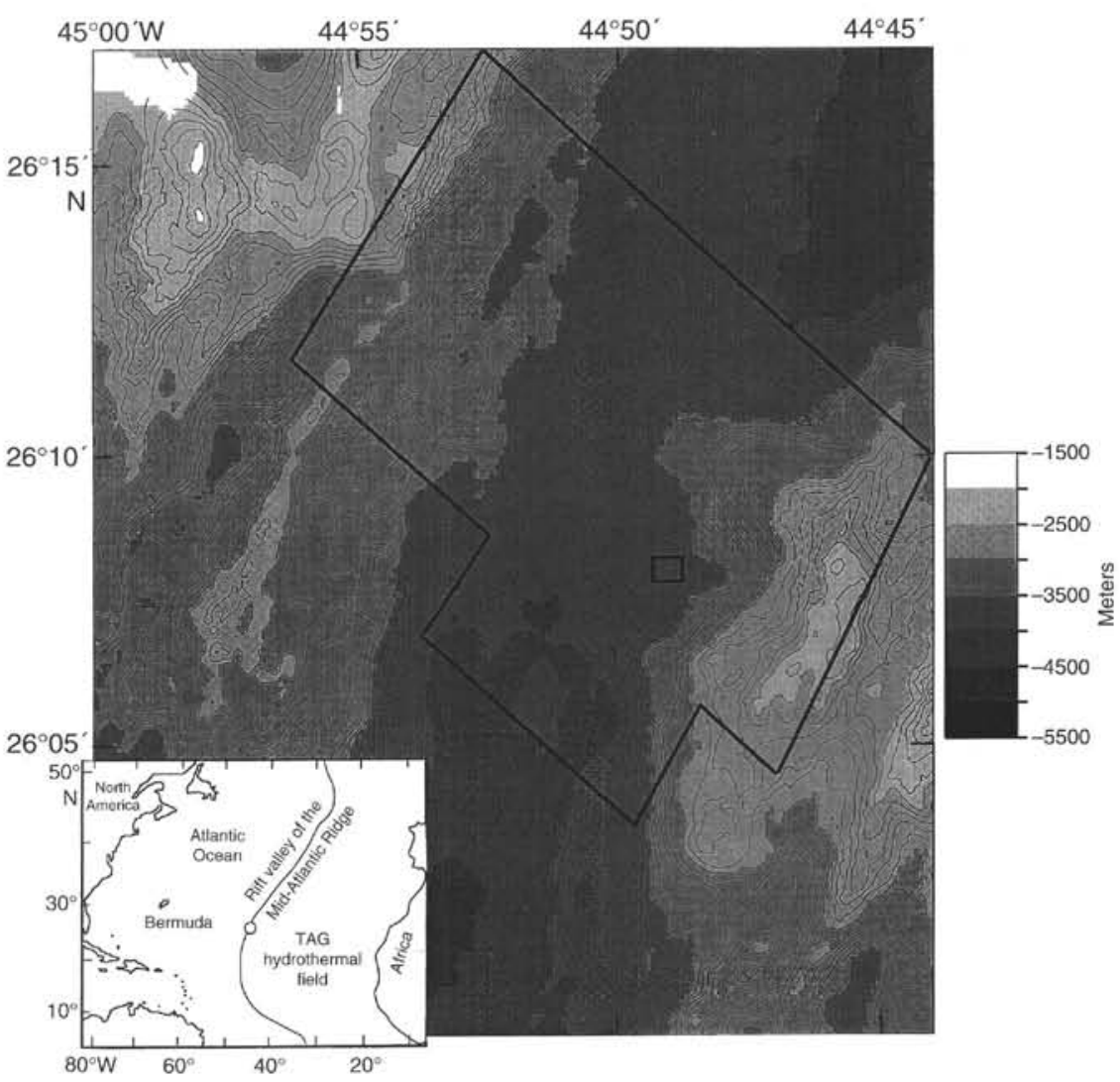

$800 \mathrm{~m}$, respectively, in real-time by means of fiber optic cable. It is towed at an altitude of about $100 \mathrm{~m}$, and a single depth measurement represents an area on the seafloor of about $2 \mathrm{~m}^{2}$ (about 4 orders of magnitude smaller than the hull-mounted systems, such as Sea Beam). This enables maps with a $2-m$ contour interval to be produced (about an order of magnitude finer than SeaBeam), resulting in much higher quality bathymetry (Kleinrock, 1992). The higher frequency of the DSL-120 (120 vs. $12 \mathrm{kHz}$ for SeaBeam) also provides sensitivity to finer features. In addition to the left- and right-looking, splitbeam sidescan sonars and the standard attitude, heading, and depth sensors, several other instruments were mounted on the DSL-120 towed vehicle: a 4-kHz sub-bottom profiler, a conductivity-temperature-depth (CTD) sensor, an oxidation potential (Eh) sensor, and a three-axis flux-gate magnetometer. During the Knorr cruise, the DSL-120 instrument package was generally towed at an altitude of $100 \mathrm{~m}$ along $023^{\circ}$-trending, structure-parallel lines spaced $300-700$ $\mathrm{m}$ apart. This strategy provided essentially $100 \%$ bathymetric and $>100 \%$ sidescan coverage of the entire region.

The second stage of the nested strategy comprised a thorough, detailed survey of the active TAG hydrothermal mound (covering an area of about $500 \times 300 \mathrm{~m}$ ), as well as a brief investigation of the inactive Alvin hydrothermal zone to the north and the eastern rift valley wall, using the Argo-II. This survey was conducted using the highresolution bathymetric map generated from phase-difference data from the DSL-120 sidescan sonar system during the first stage of our survey strategy. Argo-II is a near-bottom, remotely operated vehicle (ROV) (towed at altitudes of $\sim 3-15 \mathrm{~m}$ above the seafloor) that was configured with five video cameras (including a down-looking charged-couple device (CCD) color camera and four black and white cameras, two down-looking and two forward-looking), a down-looking electronic still camera (ESC), a 35-mm down-looking still camera, a $200-\mathrm{kHz}$ split-beam sidescan sonar system, an Imagenex $675-$ $\mathrm{kHz}$ across-track-scanning sonar profiler, a transmissometer, an Eh sensor, a CTD sensor, a three-axis magnetometer, incandescent and strobe lights, high-resolution attitude/heading/depth sensors, and a $120-\mathrm{kHz}$ sonar altimeter. Of primary importance for this operation was the collection of overlapping ESC images for purposes of making photomosaics.

A total of 68 lines were run at an altitude of about $15 \mathrm{~m}$ (to optimize coverage with the ESC and pencil-beam scanning sonar profiler, which could be monitored in real-time by means of the fiber optic cable) and with a typical line spacing of $5 \mathrm{~m}$. However, a few lower altitude tows $(\sim 5-10 \mathrm{~m})$ were conducted to obtain detailed video images and $35-\mathrm{mm}$ photographs. Most lines were run to the east and west and were generally $300-500 \mathrm{~m}$ long, with several highly oblique tie lines conducted to help in making image mosaics. In sum, we collected over 30,000 ESC images (each $\sim 8 \times 10 \mathrm{~m}$ ) at the TAG active mound; these are being used to construct a nearly complete photomosaic of the mound.

Navigation for all near-bottom work was primarily from a long baseline system of 11 acoustic transponders tethered $450-600 \mathrm{~m}$ above the seafloor in the area. Ship's navigation was determined using a classified "P-code" Global Positioning System (GPS) receiver with the permission of the U.S. government. In general, both navigation systems provided instrument locations with a repeatability of better than a few meters.

\section{REGIONAL GEOLOGY}

Shipboard compilations of preliminary DSL-120 sidescan sonar backscatter imagery and shaded relief bathymetry collected in the survey area are presented in Figure 2. For the purposes of the following discussion, we have divided the survey region into four distinct zones (numbered geographically from west to east) based on their morphology. The neovolcanic zone (Zone 2) is located roughly in the middle of the rift valley floor and is formed of a series of discontinuous volcanic regions, each of which is composed of numerous hum- 


\section{A}
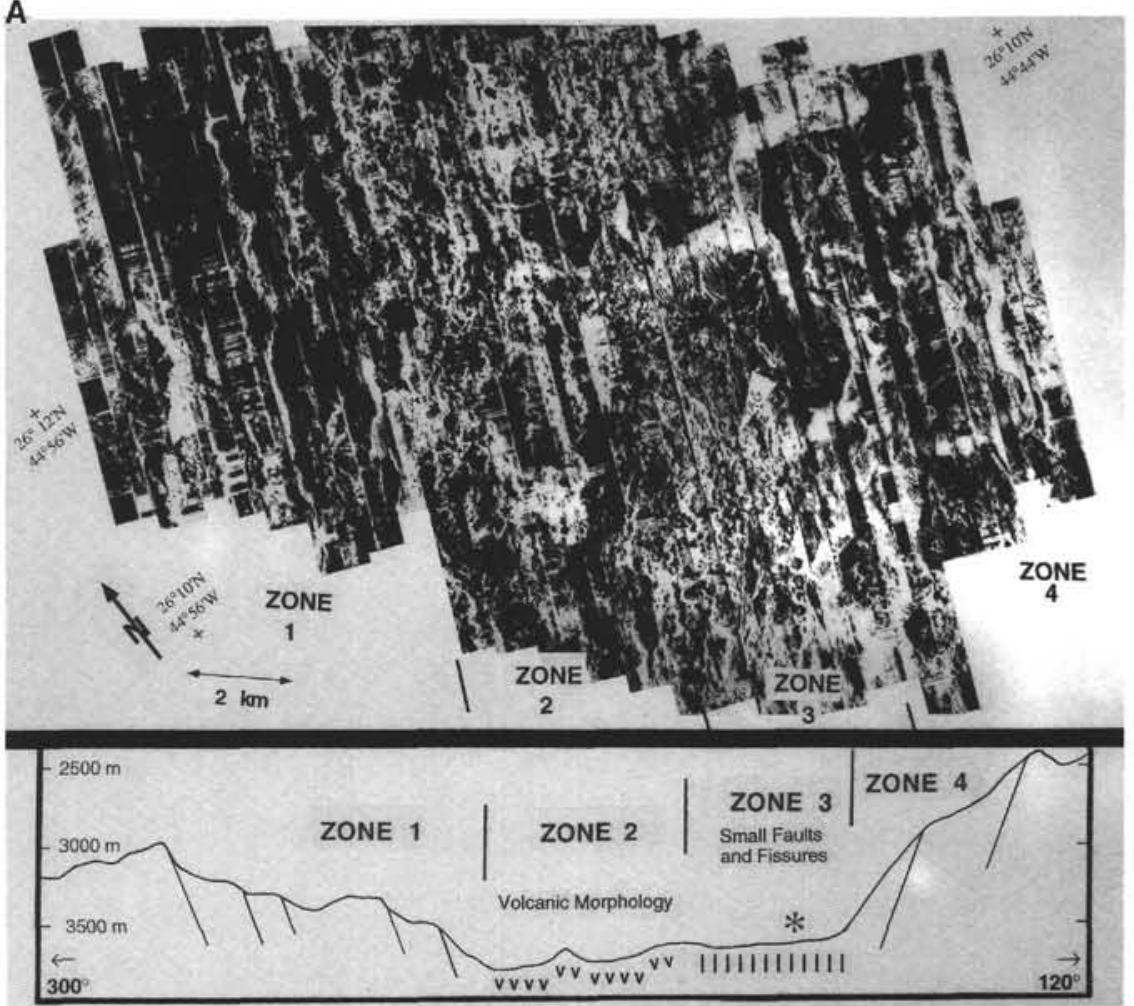

Figure 2. Shipboard compilations of preliminary DSL120 sidescan sonar backscatter imagery (A) and shaded relief bathymetry (B) collected in the survey area. All tracks shown were run at an orientation of $023^{\circ}$. In the backscatter imagery (Fig. 2A), stronger sonar returns are depicted as lighter shades and shadows are black. Note identification of TAG hydrothermal site by a white arrow labeled "TAG" to the right of center. Lower panel of Figure 2A shows SeaBeam-based bathymetric profile oriented northwest-southeast $\left(120^{\circ}-300^{\circ}\right)$ crossing the rift valley at the TAG mound. For purposes of discussion, the region is divided into four distinct zones geographically numbered from west to east, as identified in Figure 2A: Zone $1=$ terraced region to the west of the neovolcanic zone; Zone $2=$ the neovolcanic zone; Zone 3 = region of active fissuring and faulting; and Zone $4=$ terraces on the eastern rift valley wall. On the profile, significant faults are schematically shown in the subsurface as dipping lines, the TAG mound is identified by an asterisk $\left({ }^{*}\right)$, the " $v$ " symbols represent an area of unfaulted young volcanic morphology, and the vertical lines represent an area of small faults and fissures. Vertical exaggeration is 3:1. The north-pointing arrow shows that north is not straight up on this image. In Figure 2B, the preliminary DSL-120 bathymetry is superimposed on a portion of the Sea Beam bathymetry shown in Figure 1. Illumination of the shaded relief bathymetry is from the west. Note the much improved resolution of DSL-120 bathymetry over Sea Beam bathymetry. Artifacts identified in this image include the seam between the Sea Beam and DSL-120 data sets and seams between neighboring DSL-120 tracks.

B

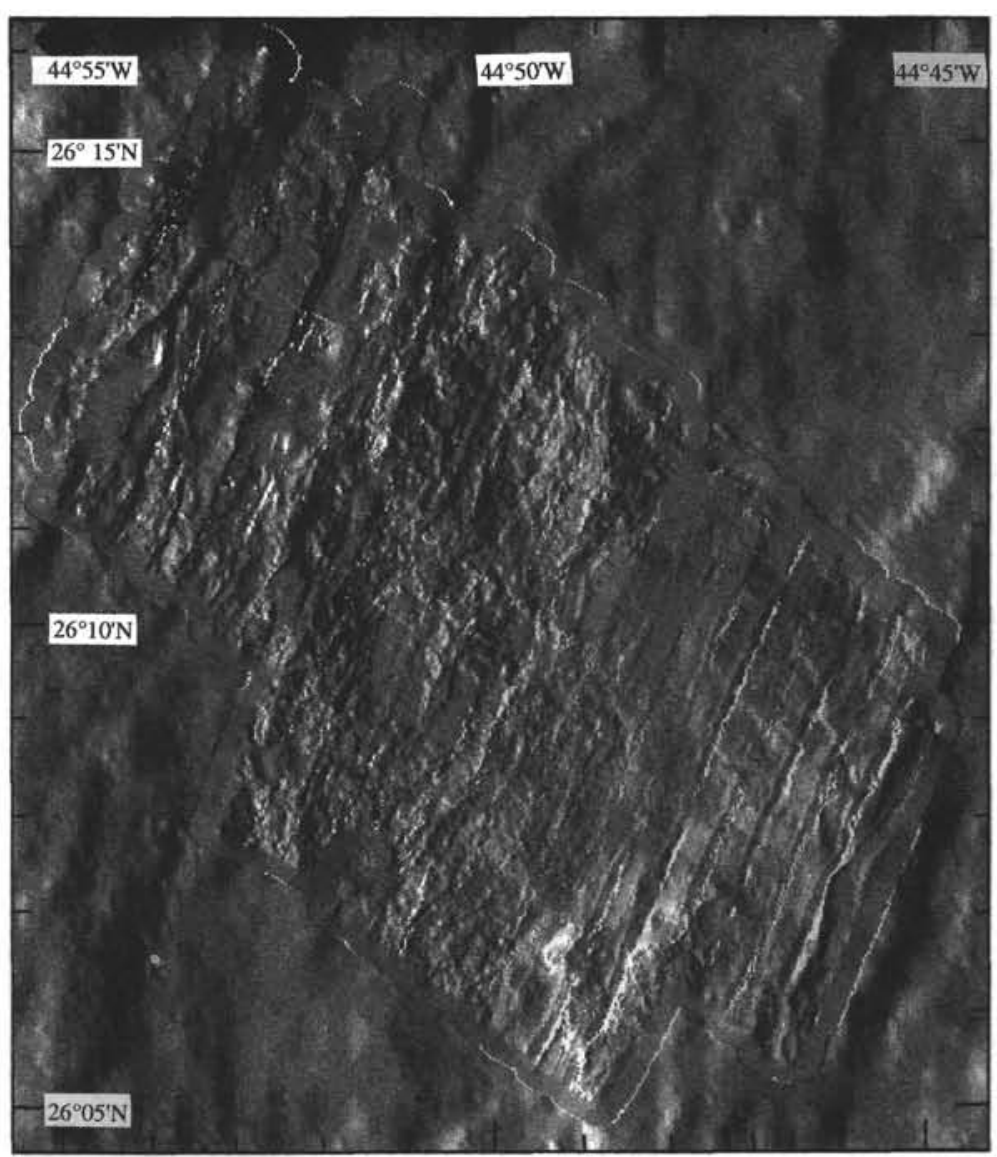


mocks. This $\sim 4-\mathrm{km}$-wide zone is distinctive in the sidescan data for its bright, semicircular sonar returns and its pronounced lack of structural fabric; it is composed of unfissured, relatively fresh volcanics.

Seafloor spreading rates at the TAG segment are known to have been asymmetric over the last $10 \mathrm{~m}$. y., with half-spreading rates of $13 \mathrm{~mm} / \mathrm{yr}$ to the east and $11 \mathrm{~mm} / \mathrm{yr}$ to the west (McGregor and Rona, 1975; McGregor et al., 1977). Comparison of the structure of the median valley floor on either side of the neovolcanic zone indicates that there are some striking differences (Kleinrock et al., 1994). West of the neovolcanic zone, the median valley floor is composed of a set of older, uplifted terraces that are heavily sedimented (Zone 1). Acoustic targets are primarily a small number of well-developed, rift-parallel faults spaced about $1.5 \mathrm{~km}$ apart. The easternmost of these faults abuts the neovolcanic zone, creating a significant geological and age boundary between Zones 1 and 2. Progressing to the west, the accumulated throw on rift-parallel faults creates the western wall of the axial rift valley. Based on isolated camera tows and submersible dives, the western wall has been described as consisting of fault-controlled basaltic scarps of 50 to $200 \mathrm{~m}$ separated by sediment-covered terraces (Eberhart et al., 1988; Lisitsyn et al., 1989; Zonenshain et al., 1989). The more complete coverage provided by our data documents that the progressive, gradual development from small rift valley floor faults into larger throw faults constituting the rift valley wall is continuous along at least $10 \mathrm{~km}$ of the ridge segment.

East of the neovolcanic zone, the paucity of sediment inferred from the sidescan and bathymetric data suggests that this area (Zone 3 ) is of an age intermediate between the neovolcanic zone (Zone 2) and the older seafloor to the west (Zone 1). The seafloor in Zone 3 is disrupted by closely spaced (several meters to approaching $100 \mathrm{~m}$ ), rift-parallel (north-northeast) fissures and faults. The southern portion of Zone 3 contains an additional set of faults, with an east-northeast trend. The TAG active hydrothermal mound lies within the region of intersection of these two prominent fault sets (Kleinrock et al., 1994). This can be seen in more detail in Figure 3, which shows an individual swath of sidescan and shaded relief bathymetric data covering the TAG active mound and the surrounding seafloor. Synthesizing sidescan and bathymetry data from the DSL- 120 with more limited Argo-II photographic data, we infer that the westernmost 1 or $2 \mathrm{~km}$ of Zone 3 is an area of active fissure development. Total extension increases to the east and becomes progressively concentrated on selected fissures and faults (Shaw et al., 1994). About $50 \mathrm{~m}$ to the east of the TAG active mound, we observed an approximately $20 \mathrm{~m}$ high fault, which is now referred to as the Argo-II fault. The presence of fresh basaltic talus at the base of this fault suggests that it is currently active, showing that this area is actively extending.

The data from the eastern portion of Zone 3 on the rift valley wall show evidence for faulting and significant amounts of mass wasting, as previously shown (Temple et al., 1979; Eberhart et al., 1988; Zonenshain et al., 1989; Karson and Rona, 1990). This wall contains many small faults whose accumulated throw creates the relatively steep eastern rift valley wall. Although most of the faults appear to dip inward toward the rift valley floor, several significant faults dip outward away from the rift axis. No evidence for an east-west fault continuing from the rift shoulder to intersect the rift valley floor at the TAG active mound site, such as that suggested by (Karson and Rona 1990) was observed. A large salient protruding from the east wall appears, however, to be bounded on its north side by an east-west fault whose nature and origin are still poorly understood. Mass wasting of the east wall appears to be ongoing. About $5 \mathrm{~km}$ from the TAG active mound in the direction $037^{\circ}$, the sidescan imagery shows the trace of one of the outward (east) dipping faults on the salient. The region uphill (i.e., to the east) from the fault has a very bright backscatter character in this imagery, and photographs taken during the Argo-II transect across this area show that this region is dominated by fresh, unsedimented talus. Near the central part of the outward-dipping

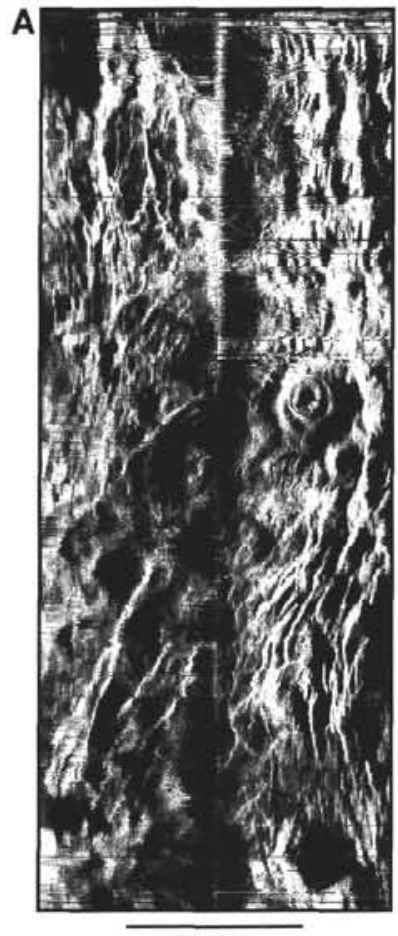

$0.5 \mathrm{~km}$

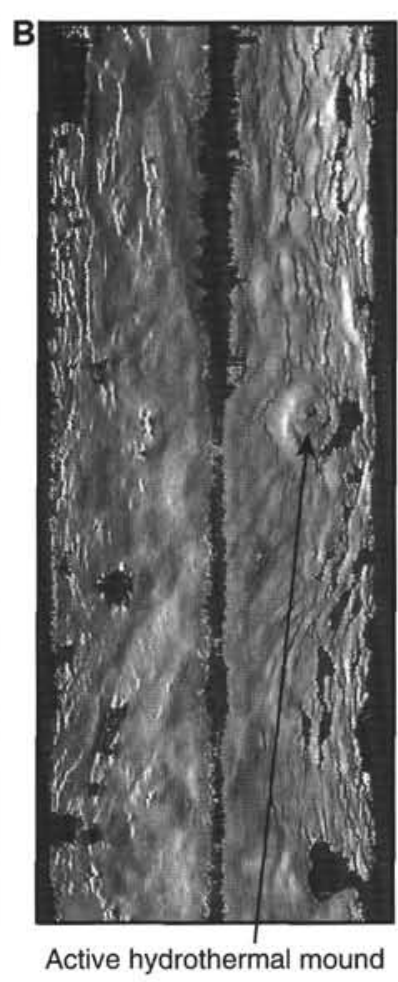

Figure 3. A swath of DSL-120 sidescan sonar backscatter imagery (A) and shaded relief bathymetry of the TAG active mound (B) and its immediate environs. Swath width is about $1 \mathrm{~km}$.

fault, the fault has been breached by a rock slide that has deposited talus continuously to a point far downhill. Photographs from this lower region show that the new unsedimented talus overlies an older, partially sedimented deposit of talus that presumably occurred by similar processes.

Zone 4 exhibits a similar sedimented terrace and fault morphology as Zone 1, although the terrace widths in Zone 4 are narrower (generally $<1 \mathrm{~km}$ ). If we assume that similar processes led to the development of these similar morphologies, then one might expect a region representing the intermediate stage of early fissure and fault growth (cf. Zone 3 ) to be present immediately to the west of the neovolcanic zone (Zone 2). However, such a zone was not observed. This asymmetry in morphology suggests the following simplified evolutionary sequence. Initially, Zone 3 represented the neovolcanic zone, separating the older Zones 1 and 4, which were presumably being faulted and fissured at that time; Zone 2 did not yet exist. Subsequently, the locus of volcanic activity became concentrated at the westernmost edge of Zone 3 . Continued crustal construction there resulted in the development of Zone 2 as the new neovolcanic zone. Meanwhile, Zone 3 was rafted off to the east, where it is presently undergoing fissuring and faulting. The net result of this history is the preferential accretion of crust to the east. Episodes of accretion such as this, which preferentially raft material to the east, contribute to the asymmetry in half-spreading rates $(13 \mathrm{~mm} / \mathrm{yr}$ to the east, $11 \mathrm{~mm} / \mathrm{yr}$ to the west) calculated over the last 3.5 m.y. (McGregor et al., 1977).

\section{GEOLOGY OF THE TAG ACTIVE MOUND}

A preliminary high-resolution bathymetric map of the TAG active hydrothermal mound has been constructed from the DSL-120 side- 
scan sonar data (Fig. 4). Although previous descriptions of the general morphology of this feature were based on observations from submersibles (Thompson et al., 1988; Rona et al., 1993; Tivey et al., 1995), this is the first time that the mound has been mapped in detail. The mound is distinctly circular in shape (Figs. 3, 4), about $200 \mathrm{~m}$ in diameter, and is located on seafloor that increases in depth from about $3660-3670 \mathrm{~m}$ on the south and east sides of the mound to $>3680 \mathrm{~m}$ on the north and west sides of the mound. The controls on the striking circularity of the TAG active mound have not yet been determined, but may be related to either geologic controls and its association with a volcanic edifice, or structural controls resulting in axisymmetric venting of hydrothermal fluids. Whether this increase in depth is indicative of gently sloping terrain or of faulting beneath the mound is unclear at present. The mound itself comprises two well-defined platforms that may represent different phases of active growth (Humphris et al., 1994). The top of the lower platform is approximately $140 \mathrm{~m}$ in diameter and is at a depth of $3650-3654 \mathrm{~m}$. The superposition of the upper platform on the north-northwest portion of the lower platform has resulted in asymmetric exposure of the lower platform. Along the northern and northwestern edges of the mound, the scarps are steep and show evidence of mass wasting. The slope is continuous from the surrounding seafloor to the upper platform, and the lower platform cannot be distinguished. Most of the surface deposits on the lower platform are exposed on the southern and eastern sides of the mound, where the platform is up to $45 \mathrm{~m}$ wide. In addition, the white smoker ("Kremlin") area that has been previously described (Thompson et al., 1988; Rona et al., 1993; Tivey et al., 1995) is located in the southeastern portion of this platform (Fig. 4). Along the edge of the platform in this region of the mound, a narrow (up to $25 \mathrm{~m}$ across), discontinuous lip shoals to depths of up to $3644 \mathrm{~m}$. The scarps of the lower terrace on the southern and eastern sides of the mound show a gradual transition from mound sulfides into the regional pelagic sediment cover.

The upper platform is up to $90 \mathrm{~m}$ in diameter, and its surface is at a depth of $3642-3648 \mathrm{~m}$. Although parts of this platform are quite flat, particularly in the southern portion, there are two distinctive morphologic features with greater relief. Just to the west of the center of this platform lies the Black Smoker Complex which is the focus of vigorous discharge of high-temperature (up to $363^{\circ} \mathrm{C}$ ) fluids through chimneys located on the summit of a cone (Thompson et al., 1988; Rona et al., 1993; Tivey et al., 1995). The cone-shaped structure has a base up to $20 \mathrm{~m}$ in diameter at a depth of $3640 \mathrm{~m}$ and rises to a narrow (5-10 $\mathrm{m}$ in diameter) summit at a depth of about $3630 \mathrm{~m}$. Individual black smoker chimneys on the summit cannot be distinguished because of the presence of the particulate-laden hydrothermal plume. To the east of the Black Smoker Complex, there is a depression approximately $20 \mathrm{~m}$ wide and $25 \mathrm{~m}$ long, elongated in a north-northeast-south-southwest direction. It is up to $10 \mathrm{~m}$ deep at its southern end and gradually shoals to the north.

Figure 5 shows a photomosaic of ESC images collected during the Argo- $I I$ survey of an approximately $100 \times 40 \mathrm{~m}$ section of the northern part of the mound. The surface of the mound is characterized by poorly sorted blocks of massive sulfides and, in areas near black smoker activity, corroding blocks of white massive anhydrite. Many of the exposed surfaces are colonized by anemones, with their abundance being greater away from areas of black smoker activity. In fact, anemones are distributed over much of both the upper and lower platforms, and variations in their abundance most likely reflect the distribution of diffuse venting over the surface of the mound.

Although most of the high-temperature black smoker chimneys are confined to the Black Smoker Complex (which could not be imaged because of the plume but would be just south of the center of the mosaic), it is clear that several other areas exist in which there are local sources of focused black smoker fluids on the upper platform (e.g., the cluster of three plumes of black smoker fluid labeled "1" in Fig. 5, and the line of plumes of black smoker fluid that may be discharging from a rift-parallel north-northeast fissure, labeled " 2 " in

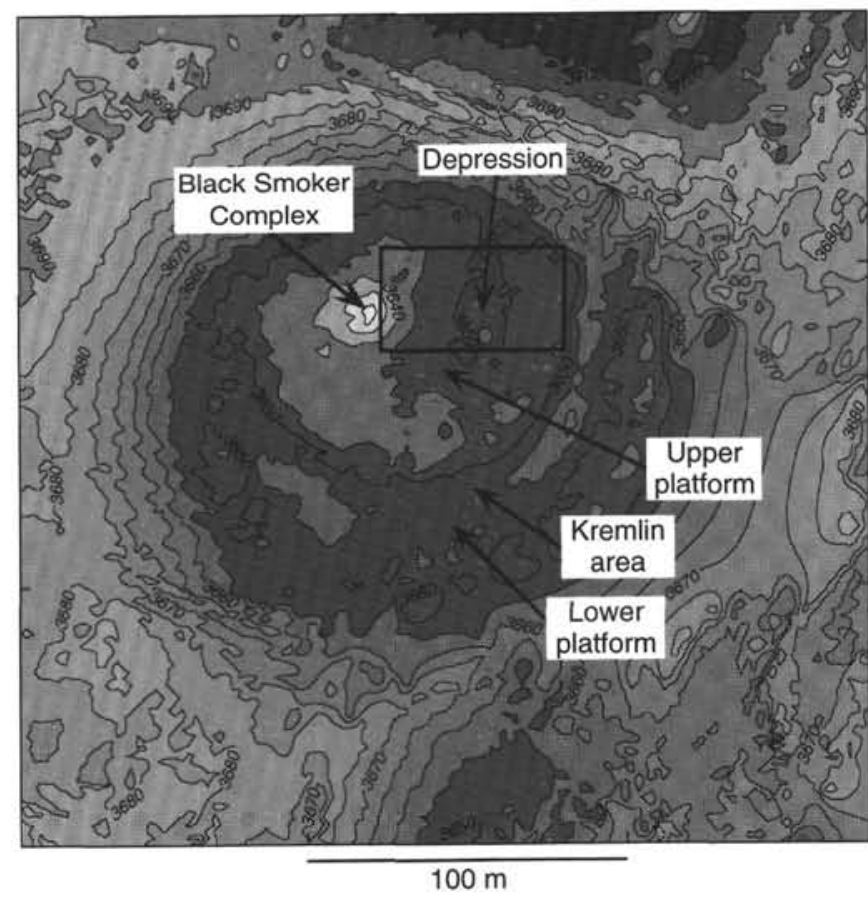

Figure 4. Preliminary 2-m bathymetric contour map of the TAG active mound derived from DSL-120 sidescan sonar data and used during Leg 158 The box shows the area covered by the photomosaic presented in Figure 5.

Fig. 5). In addition, less vigorous black smoker fluids emanate from small rift-parallel (north-northeast) fissures, creating a general haze in the water column that makes them difficult to observe from the images included in this mosaic.

The depression identified from the high resolution bathymetric map (Fig. 4) is also clearly visible on this image as an elongated feature outlined in white (labeled " 3 " in Fig. 5). Our preliminary interpretation is that it is a recent collapse feature exposing anhydrite in its walls, and blocks of anhydrite and sulfide talus on the floor (best seen in the southern circular end). Along the western side of the depression, a line of diffuse black smoker activity is likely associated with a rift-parallel fissure (labeled "4" in Fig. 5). In addition, more detailed video and photography work in this region provides evidence of a black smoker chimney, about $2 \mathrm{~m}$ high, that is currently being constructed on the southwestern lip of this depression. These features may all be the surficial expression of recent changes in the subsurface circulation system, possibly related to active fissuring.

\section{LOCALIZATION OF HYDROTHERMAL UPFLOW AT THE TAG ACTIVE MOUND}

The DSL-120 sidescan sonar data in the vicinity of the TAG active mound, and the bathymetry and photographic imagery of the mound itself, provide evidence of currently active fissuring and faulting at this location. This suggests that this portion of the eastern median valley is in a phase of activity dominated by extension rather than volcanism.

Three hypotheses have been proposed for the localization and long-lived nature of hydrothermal upflow at the TAG active mound. Based primarily on observations in the low-temperature field, Scott et al. (1974), Temple et al. (1979), and Thompson et al. (1985) suggested that hydrothermal activity was associated with listric, ridge axis-parallel faults that provide the pathways for upwelling hydrothermal fluids heated by a source most likely at the neovolcanic axis. Alternatively, discrete volcanic centers may act as the heat source for 


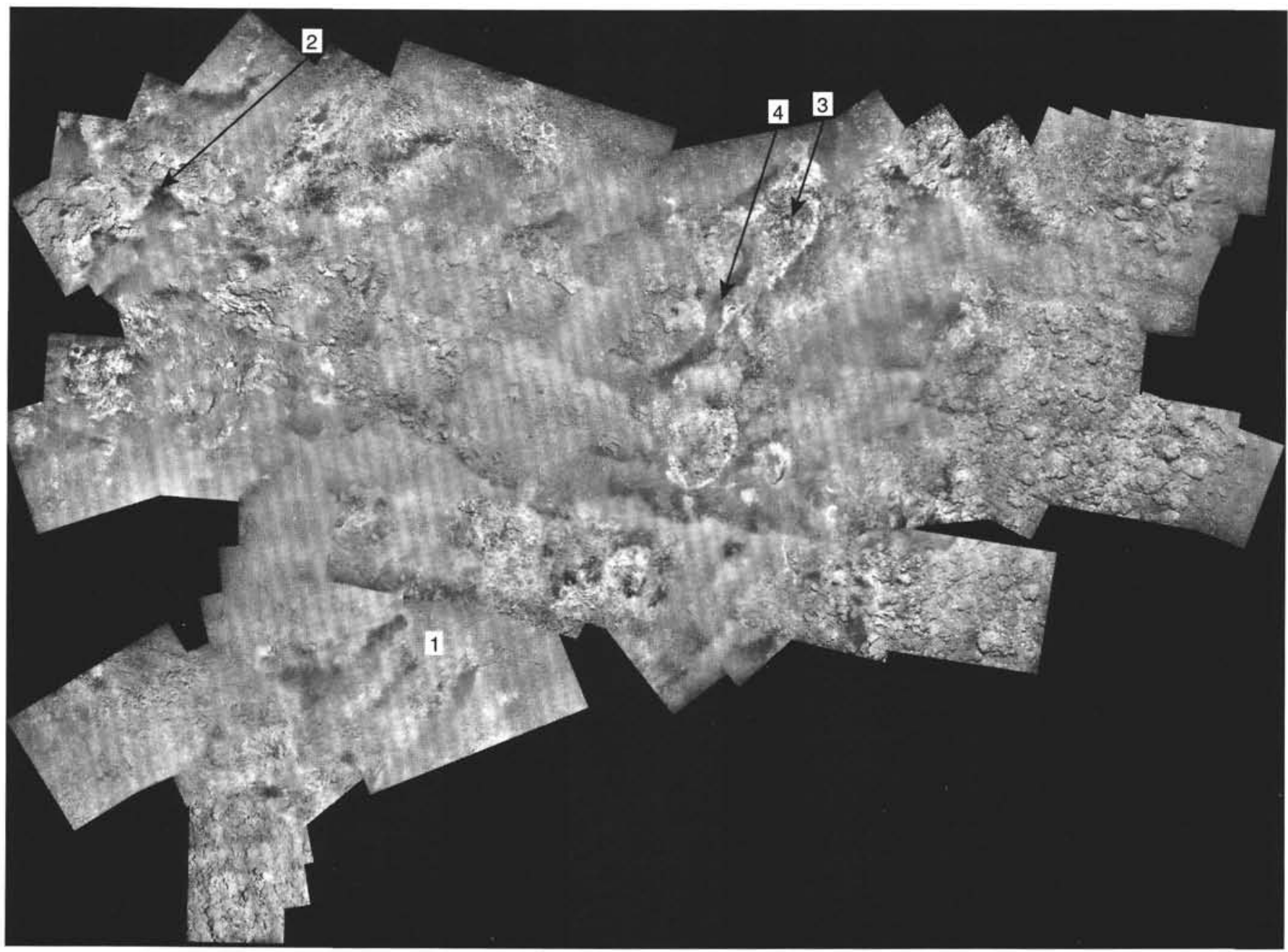

Figure 5. Preliminary photomosaic of ESC images of the portion of the TAG active mound shown by the box in Figure 4. Labeled features are as follows: $1=$ cluster of three plumes of black smoker fluid not associated with the main Black Smoker Complex; 2 = black smoker fluids discharging from a rift-parallel north-northeast fissure; 3 =elongated depression to the east of the Black Smoker Complex; and $4=$ line of diffuse black smoker fluid probably venting from a rift-parallel fissure along the western side of the depression.

localized hydrothermal activity. Support for this hypothesis comes from Zonenshain et al. (1989) who noted very recent volcanics, as well as older basalt outcrops, associated with the presently active mound, suggesting intermittent volcanic activity, with a very recent eruption. Third, based on observations of east-west faults high on the eastern wall, Karson and Rona (1990) suggested that these faults may intersect the ridge-parallel faults, concentrating hydrothermal activity at the intersections.

Preliminary analyses of our survey data provide no clear evidence for the existence of a young volcanic structure in the vicinity of the TAG active mound. Therefore, the nature and location of the heat source driving the hydrothermal circulation remains enigmatic.

No clear evidence exists to indicate that any valley floor fissures or faults continue up onto the eastern median valley wall and link with the east-west faults observed there by Karson and Rona (1990). However, our data do establish that the mound resides in a zone of actively developing ridge-parallel fissures and faults (the most developed of which is the Argo- $I I$ fault) that intersect a series of obliquely oriented (east-northeast) faults (Kleinrock et al., 1994). It is likely, therefore, that the active features provide conduits for the upflow of hydrothermal fluids, with focusing of the flow along the highly permeable channels at specific intersections of the two sets of faults.

\section{CONCLUSIONS}

Preliminary analyses of the survey data collected from a portion of the median valley in the TAG segment and from the TAG active mound provide the following observations and conclusions:

1. There is strong asymmetry in the age of rocks within the rift valley.

2. The relatively unfissured neovolcanic zone is located roughly in the middle of the rift valley floor. It is formed of a series of discontinuous volcanic regions, each of which is made up of numerous small hummocks.

3. A sharp fault bounds the neovolcanic zone on the west, separating it from an uplifted sedimented terrace of significantly older age to the west.

4. East of the neovolcanic zone is a more gradual aging of seafloor, with progressive development of rift-parallel fissures and faults and a concomitant increase in extension. Accumulation of throw on these faults contributes to the relief of the rift valley wall.

5. Asymmetry in the morphology and age distribution about the spreading axis suggests a recent episode of preferential accretion of crust to the east. Such episodes in the past have likely contributed to 
the long-term asymmetry in half-spreading rates $(13 \mathrm{~mm} / \mathrm{yr}$ to the east, $11 \mathrm{~mm} / \mathrm{yr}$ to the west).

6. The TAG active mound resides in a zone of actively developing ridge-parallel (north-northeast) fissures at the intersection of this zone with a series of preexisting obliquely oriented (east-northeast) faults. These east-northeast faults do not appear to link with faults previously described from the upper portions of the rift valley walls. Preliminary analysis suggests that this intersecting fault pattern plays an important role in the localization of hydrothermal activity at the active TAG mound.

7. Contemporaneous tectonic deformation and hydrothermal deposition continue to modify the three-dimensional structure and hydrogeology of the TAG active mound.

\section{ACKNOWLEDGMENTS}

The National Science Foundation supported this work through NSF Grant No. OCE-9314697. We thank the crew of the Knorr for their professional efforts which led to a successful field program. We are very much indebted to $\mathrm{G}$. Thompson for his long-term encouragement and support in bringing this expedition to fruition. We also appreciate the considerable efforts of H. Schouten and M.A. Tivey in planning this survey. Helpful reviews by E. Davis and J. Karsten improved the manuscript. This is WHOI Contribution Number 8983.

\section{REFERENCES}

Campbell, A.C., Palmer, M.R., Klinkhammer, G.P., Bowers, T.S., Edmond, J.M., Lawrence, J.R., Casey, J.F., Thompson, G., Humphris, S., Rona, P.A., and Karson, J.A., 1988. Chemistry of hot springs on the Mid-Atlantic Ridge. Nature, 335:514-519.

Eberhart, G.L., Rona, P.A., and Honnorez, J., 1988. Geologic controls of hydrothermal activity in the Mid-Atlantic Ridge rift valley: tectonics and volcanics. Mar. Geophys. Res., 10:233-259.

Humphris, S.E., Kleinrock, M.C., and the Deep-TAG Team, 1994. Detailed morphology and the distribution of venting at the active TAG hydrothermal mound, $26^{\circ} \mathrm{N}$, Mid-Atlantic Ridge. Eos, 75:660.

Karson, J.A., and Rona, P.A., 1990. Block tilting, transfer faults, and structural control of magmatic and hydrothermal processes in the TAG area, Mid-Atlantic Ridge $26^{\circ}$ N. Geol. Soc. Am. Bull., 102:1635-1645.

Kleinrock, M.C., 1992. Capabilities of some systems used to survey the deep-sea floor. In Geyer, R.A. (Ed.), CRC Handbook of Geophysical Exploration at Sea: Hard Minerals: Boca Raton, FL (CRC Press), 3684.

Kleinrock, M.C., Humphris, S.E., and the Deep-TAG Team, 1994. The TAG region on the Mid-Atlantic Ridge: results from a recent near-bottom survey. Eos, 75:669.

Lalou, C., Reyss, J.L., Brichet, E., Arnold, M., Thompson, G., Fouquet, Y., and Rona, P.A., 1993. New age data for Mid-Atlantic Ridge hydrother- mal sites: TAG and Snakepit geochronology revisited. J. Geophys. Res, 98:9705-9713.

Lalou, C., Thompson, G., Arnold, M., Brichet, E., Druffel, E., and Rona, P.A., 1990. Geochronology of TAG and Snakepit hydrothermal fields, Mid-Atlantic Ridge: witness to a long and complex hydrothermal history. Earth Planet. Sci. Lett., 97:113-128.

Lisitsyn, A.P., Bogdanov, Y.A., Zonenshayn, L.P., Kuz'min, M.I., and Sagalevich, A.M., 1989. Hydrothermal phenomena in the Mid-Atlantic Ridge at Lat. $26^{\circ} \mathrm{N}$ (TAG hydrothermal field). Int. Geol. Rev., 31:1183-1198.

McGregor, B.A., Harrison, C.G.A., Lavelle, J.W., and Rona, P.A., 1977. Magnetic anomaly patterns on the Mid-Atlantic Ridge crest at $26^{\circ} \mathrm{N} . J$. Geophys. Res., 82:231-238.

McGregor, B.A. and Rona, P.A., 1975. Crest of Mid-Atlantic Ridge at $26^{\circ} \mathrm{N}$. J. Geophys. Res., 80:3307-3314.

Purdy, G.M., Sempéré, J.-C., Schouten, H., Dubois, D.L., and Goldsmith, R., 1990. Bathymetry of the Mid-Atlantic Ridge, $24^{\circ}-31^{\circ} \mathrm{N}$ : a map series. Mar. Geophys. Res., 12:247-252.

Rona, P.A., Hannington, M.D., Raman, C.V., Thompson, G., Tivey, M.K. Humphris, S.E., Lalou, C., and Petersen, S., 1993. Active and relict seafloor hydrothermal mineralization at the TAG hydrothermal field, MidAtlantic Ridge. Econ. Geol., 88:1987-2013.

Rona, P.A., Klinkhammer, G., Nelson, T.A., Trefry, J.H., and Elderfield, H., 1986. Black smokers, massive sulfides and vent biota on the Mid-Atlantic Ridge. Nature, 321:33-37.

Scott, M.R., Scott, R.B., Rona, P.A., Butler, L.W., and Nalwalk, A.J., 1974. Rapidly accumulating manganese deposit from the median valley of the Mid-Atlantic Ridge. Geophys. Res. Lett., 1:355-358.

Shaw, P.A., Kleinrock, M.C., and Humphris, S.E., 1994. Growth of faults and lithospheric strength at the Mid-Atlantic Ridge. Eos, 75:649.

Temple, D.G., Scott, R.B., and Rona, P.A., 1979. Geology of a submarine hydrothermal field, Mid-Atlantic Ridge, $26^{\circ} \mathrm{N}$ latitude. J. Geophys. Res. 84:7453-7466.

Thompson, G., Humphris, S.E., Schroeder, B., Sulanowska, M., and Rona, P.A., 1988. Active vents and massive sulfides at $26^{\circ} \mathrm{N}$ (TAG) and $23^{\circ} \mathrm{N}$ (SNAKEPIT) on the Mid-Atlantic Ridge. Can. Mineral., 26:697-711.

Thompson, G., Mottl, M.J., and Rona, P.A., 1985. Morphology, mineralogy, and chemistry of hydrothermal deposits from the TAG area, $26^{\circ} \mathrm{N}$ MidAtlantic Ridge. Chem. Geol., 49:243-257.

Tivey, M.A., Rona, P.A., and Schouten, H., 1993. Reduced crustal magnetization beneath the active sulfide mound, TAG hydrothermal field, MidAtlantic Ridge $26^{\circ} \mathrm{N}$. Earth Planet. Sci. Lett., 115:101-115.

Tivey, M.K., Humphris, S.E., Thompson, G., Hannington, M.D., and Rona, P.A., 1995. Deducing patterns of fluid flow and mixing within the TAG active hydrothermal mound using mineralogical and geochemical data. $J$. Geophys. Res., 100:12527-12555.

Zonenshain, L.P., Kuzmin, M.I., Lisitsin, A.P., Bogdanov, Y.A., and Baranov, B.V.. 1989. Tectonics of the Mid-Atlantic rift valley between the TAG and MARK areas $\left(26-24^{\circ} \mathrm{N}\right)$ : evidence for vertical tectonism. Tectonophysics, 159:1-23.

\section{Ms 158IR-102}

